\title{
PERAN WARNA PADA INTERIOR RUMAH SAKIT UNTUK \\ MENCAPAI KENYAMANAN DALAM KAITANNYA \\ PENYEMBUHAN PASIEN RAWAT INAP
}

Made Ida Mulyati

Desain Interior Fakultas Seni Rupa dan Desaim ISI Denpasar

\section{Abstrak}

Keberhasilan proses penyembuhan pasien merupakan komleksitas yang terjalin antara kondisi fisiologis dengan kondisi psikologis (inner mind) Kedua kondisi tersebut memiliki kontribusi di dalam proses penyembuhan pasien. Untuk mendukung kondisi pisikologis yang baik terhadap pasien, maka harus diciptakan lingkungan interior yang nyaman. Sedangkan yang dapat mendukun kenyamanan ruang salah satunya adalah penerapan warna yang tepat pada rungruang perawate terutoma pada kamar rawat inap. Dengan perapa tepat diharapan dapat mereduksi faktor strees pada pasien terutama pasien raw

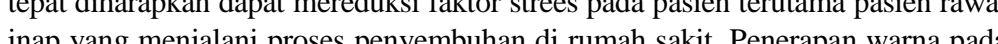
anap yang menjalani proses penyenbuhan di mon sakit. Pencrapan warna pada desain interior rumah sakit terutama pada kamar rawat inap ditentukan oleh konsep ruang yang dipilih. Untuk menentukan konsep ruang yang dipilih kita harus tahu dimensi besaran ruangnya dan ketinggi plafondnya. Untuk ruang kamar rawat inap tidak terlalu luas dan memiliki ketinggian plafond yang tidak terlalu tinggi, maka kita bias mengambil konsep tenang (calm) atau konsep segar (fresh). Dalam konsep tenang(calm) dapat diterapkan warna-warna lembut yang elegan. Sedangkan untuk konsep segar (fresh) dapat diterapkan warna-warna muda yang mengambil inspirasi dari alam. Tetapi di dalam penerapan konsep ini tidak menutup kemungkinan untuk menerapkan warna-warna hangat sebagai aksentuasi supaya terkesan lebih hidup tidak terlalu moneton. Apabila kamar rawat inap memiliki besaran ruangan yang cukup luas dengan ketinggian plafond ang cuk , mak dapt meng yang cukup, marna-warna konsep in dikomban want-wanna hangat, tetapi tidak mentup kemungkinan kesan nyaman.

Kata kunci: konsep warna, interior, dan efek kenyamanan

\section{PENDAHULUAN}

Banyak orang awam berpendapat bahwa penyembuhan penyakit atau pemulihan penyakit hanya tergantung pada medis saja. Akan tetapi faktor pendukung yang dominan bagi kesembuhan atau pemulihan penyakit terutama pasien rawat inap adalah faktor pisikologi. Melihat kenyataan dilapangan sangat banyak faktor tersebut diabaikan karna dianggap tidak penting (Kapian dkk,1993)

Faktor psikologi dapat membantu penyembuhan atau pemulihan penyaki terhadap pasien terutama rawat inap. Salah satu yang mempengaruhi faktor pisikologi pasien adalah suasana ruang yang nyaman. Sedangkan yang dapat 
mendukung kenyamanan ruang salah satunya adalah penerapan warna yang tepat pada interior, terutama pada ruang rawat inap. Dengan penerapan warna yang tepat diharapkan dapat mereduksi faktor stress pada pasien terutama pasien rawat inap yang menjalani proses penyembuhan di rumah sakit.

Proses penyembuhan pasien rawat inap tidak hanya diperlukan pada rumah-rumah sakit swasta atau rumah sakit pemerintah kelas vip, tapi kelas ekonomi juga sebaiknya diperhatikan. Sedangkan pada umumnya kebanyakan yang kita lihat sekarang ini ruang rawat inap kelas ekonomi terutama pada rumahrumah sakit yang dikelola pemerintah kurang memperhatikan suasana ruang sehingga faktor kenyamanan dan pisikologi pasien dapat dikatakan terabaikan. Dengan keadaan ruang yang demikian, fungsi ruang tidak akan optimal dalam membantu proses penyembuhan pasien rawat inap (Utomo,1999).

Unuk mengoptimalkan fungsi ruang dalam hal ini ruang rawat inap di rumah sakit perlu diadakan pendekatan holistic. Dengan pendekatan holistic maka proses penyembuhan pasien dapat dilakukan lebih optimal karena kondisi pisikologis dan psikologis (inner mid) dari pasien merupakan kompleksitas yang harus terjalin guna membantu proses penyembuhan pasien. Untuk mendukung kondisi pisikologis pasien terutama pasien rawat inap maka perlu diciptakan lingkungan yang nyaman untuk memberikan dukungan yang positif bagi penyembuhan pasien. Salah satunya lingkungan yang nyaman dengan menerapkan warna-warna yang sesuai dalam interior ruang rawat inap untuk menciptakan suasana yang nyaman. Menurut Kaplan dkk(1993), dalam konteks tersebut faktor-faktor yang berpengaruh terhadap proses penyembuhan pada pasien antara lain $40 \%$ faktor lingkungan, $10 \%$ medis, $20 \%$ genetis dan $30 \%$ faktor lain seperti sugesti, biyaya, dukungan moril dari keluarga atau orang terdekat dengan pasien.

Manusia dan lingkungan pada pada dasarnya merupakan satu kesatuan yang tidak dapat dipisahkan karena keduannya saling berinteraksi. Sedangkan lingkungan dapat dibagi menjadi dua yaitu lingkungan alami dan buatan. Lingkungan alami yaitu lingkungan yang dibentuk dengan alam seperti ruang luar (exterior), sedangkan ruang buatan adalan ruang yang sengaja dibuat yang dibatasi oleh lantai, dinding dan plafond atau atap. Dalam hal ini manusi dalam menjalani kehidupan sebaiknya harus dapat berinteraksi dengan lingkungannya baik lingkungan alami maupun buatan. Dengan saling berinteraksi antara manusia dan lingkungannya maka manusia baru dapat dikatakan sempurna (Altaman,1975).

Untuk lebih mempermudah interaksi antara manusia dengan lingkungannya maka sebaiknya diciptakan lingkungan yang nyaman. Manuabe (1977), menyatakan bahwa kenyamanan adalah unsure perasaan seseorang akibat minimalnya gangguan pada sensasi tubuh.
Untuk itu di dalam interaksi antara pasien rawat inap dengan lingkungannya yang terasa asing maka sebaiknya difikirkan bagaimana menciptakan kondisi lingkungan yang nyaman , salah satunya penerapan warna yang berkaitan dengan visual yang dapat mempengaruhi aspek psikologi dalam diri pasien terutama pasien rawat inap.

\section{ASPEK PSIKOLOGIS WARNA DALAM DESAIN INTERIOR}

\section{Presepsi Psikologis dalam Desain Interior}

Presepsi adalah pengenalan dan penilaian oleh otak sebagai hasil sensai dari pengindraan yang dilakukan oleh setiap sel-sel syaraf reseptor atau indra yang dimiliki manusia, yaitu indra pengelihatan (visual), pendengaran (aural), penciuman (alfaktory), perabaan (tactile), perasaan oleh suhu tubuh terhadap panas (thermal).

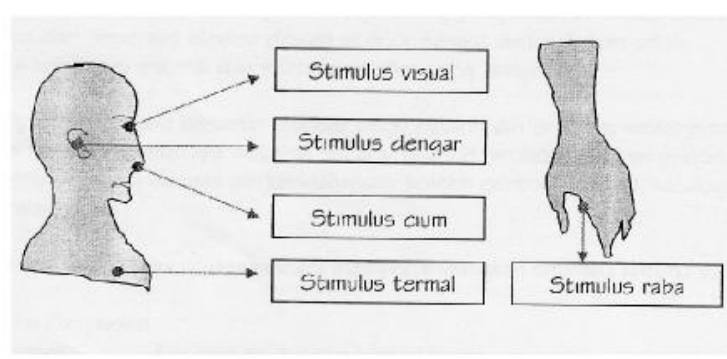

Skema 1 Proses Pengindraan

Pengindraan yang menimbulkan presepsi tidak dapat dilepaskan dari pengalaman masa lalu, seperti contoh seorang melihat warna daun pisang yang mengarah kekuningan (hijaunya terang) akan diorganisir di dalam pencitraan, untuk kemudian dikaitkan dengan masa lalu untuk memaknai jenis warna hijau terang tersebut sebagai hijau daun pisang. Proses seperti ini disebut dengan colorvisme, sementara pengenalan warna tersebut disebut aktivitas mental, yang juga disebut kegiatan kognisi. Jadi otak akan selalu aktif untuk menilai dan member makana terhadap setiap unsure lingkungan yang diterima oleh indra manusia. Sedangkan fungsi aktif dari kesadaran manusi disebut sebagai pandangan "Fungsionalisme". Pendekatan ini disebut sebagai pendekatan ekologik yang ditemukan oleh Gibson (Sarwono,S.1995), dimana beliau mengatakan bahwa manusia tidak menciptakan makan-makna dari proses pengindraan, tetapi sudah terkandung dalam stimulasi itu sendiri yang tersedia untuk diserap oleh setiap mahluk yang menyerapnya. Ia pun mengemukakan bahwa presepsi berlangsung spontan ,langsung dan bersifat holistic. Presepsi tersebut mendorong otak untuk memperintahkan syarap motorik untuk bereaksi 
secara spontan terhadap lingkungan. Proses presepsi ini dapat dilihat di dalam skema 1 .

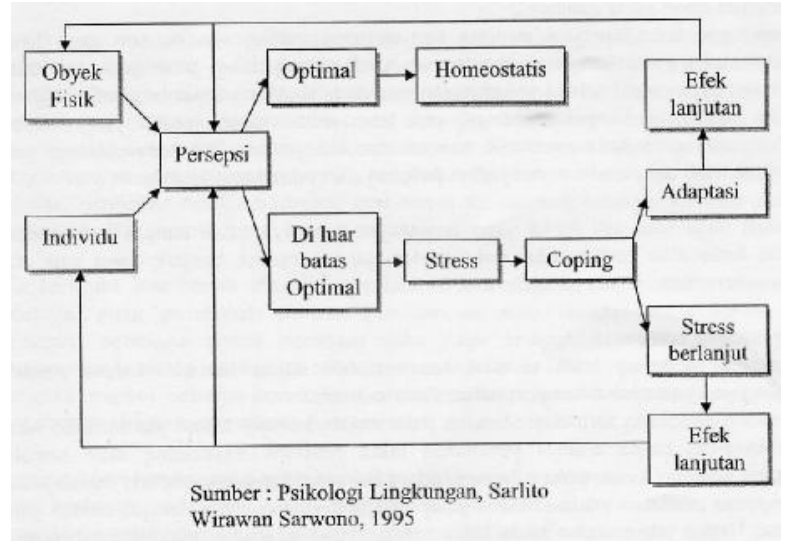

Skema 2 Proses Persepsi

Dengan suasana lingkungan yang tidak nyaman sehingga dalam kondisi tertentu manusia tidak bias menyesuaikan diri atau dapat dikatakan presepsi psikologinya tidak optimal. Apabila hal tersebut terjadi dalam jangka waktu yang lama maka dapat menimbulkan stress yang berkelanjutan mengakibatkan kebosanan, perasaan kesal tidak berdaya, hingga sampai pada kondisi frustasi. Seperti salah satu contoh apabila seorang desainer interior melakukan kesalah dalam menerapkan warna-warna pada interior ruang perawatan terutama pada ruang rawat inap sehingga mengakibatkan kondisi ruang tidak nyaman, maka mempengaruhi perasaan tidak nyaman pada pasien. Hal tersebut akan menambah buruk kondisi pasien. Untuk itu seorang desainer interior seharusnya tahu dan mengerti ilmu psikologi warna untuk tidak membuat kesalahan dalam menerapkan warna-warna pada proses desain dalam hal ini proses desain interior ruang rawat inap. Penentuan warna dalam proses desain tersebut disesuaikan dengan kondisi manusia yang beraktivitas di ruang tersebut dan jenis aktivitas yang dijalankan pada ruang tersebut, sehingga presepsi psikologi pengguna ruang dapat mencapai optimal.

\section{Mengenal Warna}

Warna adalah suatu bentuk cahaya atau radiasi gelombang elektromagnetik, yang dihasilkan dari cahaya matahari yang berwarna putih. Mata manusia dapat melihat warna setelah cahaya matahari melewati sebuah prisma yang membiaskan dan memisahkan cahaya tersebut menjadi 7(tujuh) frekuensi gelombang cahaya yang berbeda yaitu : merah, jingga, kuning, hijau, nila, ungu.
Jadi seseorang bias melihat warna berkat adanya cahaya yang masuk ke mata. Untuk itu manusia tidak bias melihat warna dalam ruang yang gelap tanpa cahaya (Skinner V.J, 2001)

Salah satu yang paling mudah untuk memahami pembagian warnawarna dengan mengenal lingkaran warna (color ring). Pada lingkaran warna terdapat 12 (duabelas) warna yang terbagi atas warna primer, skunder dan tersier (Gon.H, dkk, 2008).

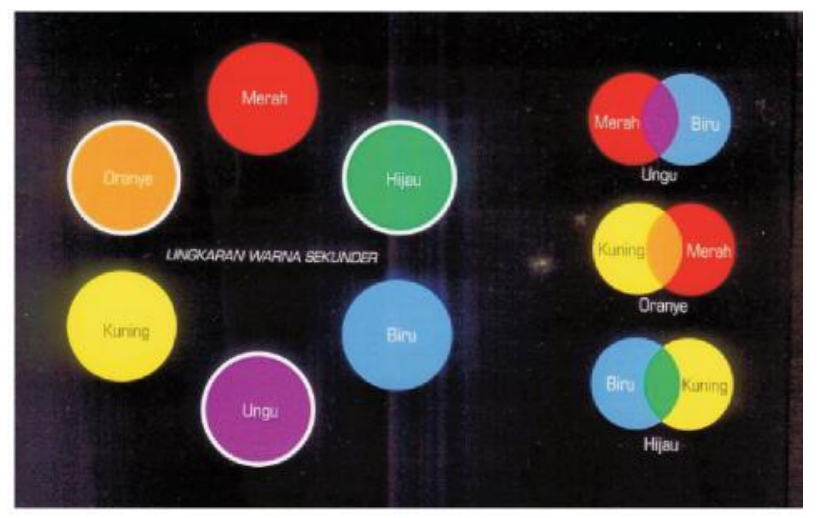

Gambar 1 Lingkaran Warna Prime

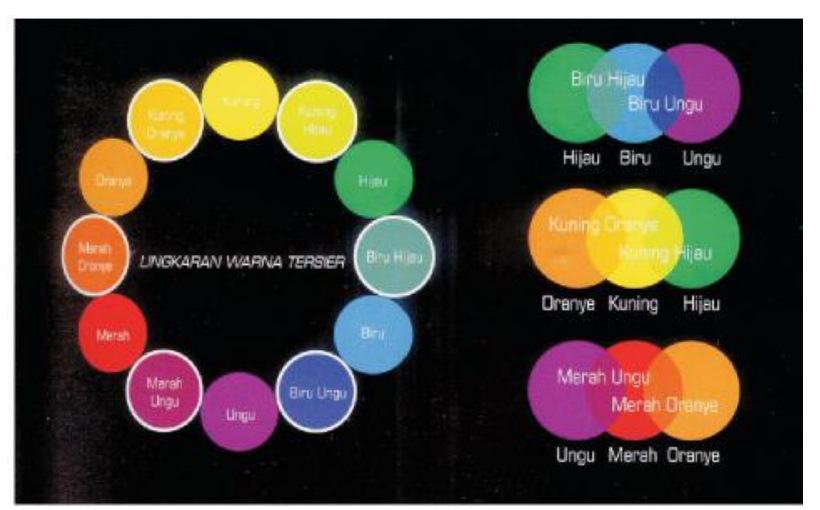

Gambar 2 Lingkaran Warna Tersier

\section{Psikologi Warna dalam Desain Interior}

Warna merupakan salah satu unsur penting dalam desain interior karena warna dapat menciptakan suasana ruang yang berkesan kuat, menyenangkan sehingga secara psikologi dapat member pengaruh emosional terhadap penggunanya (Pile,1995). 
Ditinjau dari efek psikologi dan sifat khas yang dimilikinya, maka warna dapat dibagi menjadi dua kategori yaitu kategori warna hangat dan kategori warna dingin. Warna-warna yang berdekatan dengan warana merah dan jingga digolongkan warna hangat, sedangkan warna-warna yang berdekatan dengan warna biru sampai berpuncak pada warna biru kehijauan digolongkan warna dingin (Gon.H, dkk, 2008). Dilihat dari efek fsikologi kedua kategori warna tersebut dapat mempengaruhi psikologi manusia yang melihat.

Efek psikologi golongan warna hangat seperti merah dapa membangkitkan energi, aktif, antusias, bersemangat, meningkatkan aliran darah Tetapi kalau penerapan warna merah terlalu banyak dapat merangsang kemarahan dan agresivitas. Jingga dapat menambah kekuatan intuisi, fantasi, imajinasi, kreatif juga dapat memberi inspirasi dan obsesif. Kuning dapat membangkitkan energi dan mood, warna yang penuh semangat dan vitalitas, komunikatif dan mendorong ekspresi diri, memberi inspirasi, memudahkan berpikir secara logis dan merangsang kemampuan intelektual. Sementara itu, efek psikologi warna dingin seperti biru dapat menimbulkan perasaan tenang, sejuk, tentram, hening dan damai, tapi hati-hati menerapkan warna biru dalam desain interior karena warna biru terlalu dominan bias menimbulkan kelesuan. Warna hijau menyegarkan, membangkitkan energi dan mampu memberi efek menenangkan, menyejukan, menyeimbangkan emosi dan meredakan stress,memberi rasa aman dan perlindungan, sedangkan warna lain selain warna hangat dan dingin ada warna coklat, putih, hitam dan abu-abu. Coklat merupakan warna netral yang natural, stabil, namun juga bias menjadi berat dan kaku bila terlalu mendominasi dalam interior. Putih melambangkan kemurnian dan kepolosan, memberikan perlindungan, ketentraman, tapi apabila warna putih mendominasi dalam interior dapat menimbulkan perasaan dingin, steril, kaku dan terisolir. Warna hitam merupakan warna kuat, maskulin, penuh percaya diri, megah dramatis dan misterius, tapi hitam juga merupakan lambang duka dan dapat menimbulkan perasaan tertekan apabila terlalu mendominasi dalam interior. Abu-abu termasuk warna netral, dapat menciptakan kesan serius namun juga menetramkan dan menimbulkan perasaan damai. Abu-abu juga dapat menimbulkan kesan luas dan stabil, tetapi kalau dalam penerapan interior abu-abu tua terlalu mendominasi maka ruangan akan terasa kaku dan tidak komunikatif (Gon H, dkk, 2008).

Pengaruh-pengaruh dari warna-warna tersebut dapat memberikan nilai lebih terhadap perencanaan interior suatu ruang sehingga dapat mempengaruhi faktor psikologi pemakainya sesuai dengan tujuan dan kegunaan ruang. Seperti contoh suasana ruang tenang ( $\mathrm{calm}$ ) sebaiknya memilih warna-warna lembut yang elegan sehingga menjadikan ruang terkesan luas, tentram, damai santai dan nyaman, seperti kombinasi hijau pastel, coklat pastel, putih, biru pastel, cream dll (gambar 1).

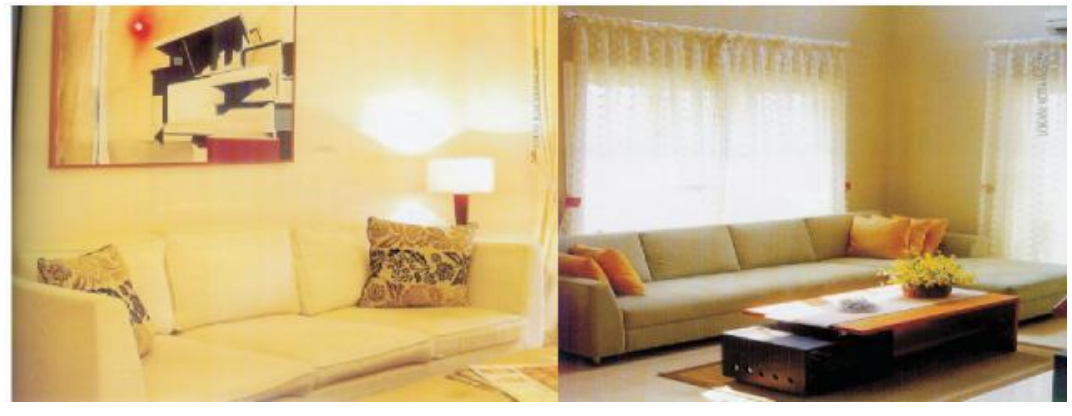

Gambar 1. Interior ruang keluarga yang menerapkan warna-warna lembut

Interior tersebut di atas pada bagian tertentu menggunakan sentuhan warna-warna hangat sebagai aksen seperti terlihat merah yang diterapkan pada sebagian pada warna lukisan dan kuning yang diterapkan pada warna sarung bantal dan rangkaian bunga meja.

Apabila suasana ruang yang diinginginkan berkesan hangat(warm) sebaiknya memilih warna-warna natural dan hangat sehingga mampu menghadirkan suasana menjadi lebih hidup, akrab, hangat dan nyaman, seperti masalnya kombinasi warna coklat, oranye, putih, merah, kuning dll (gambar.2)

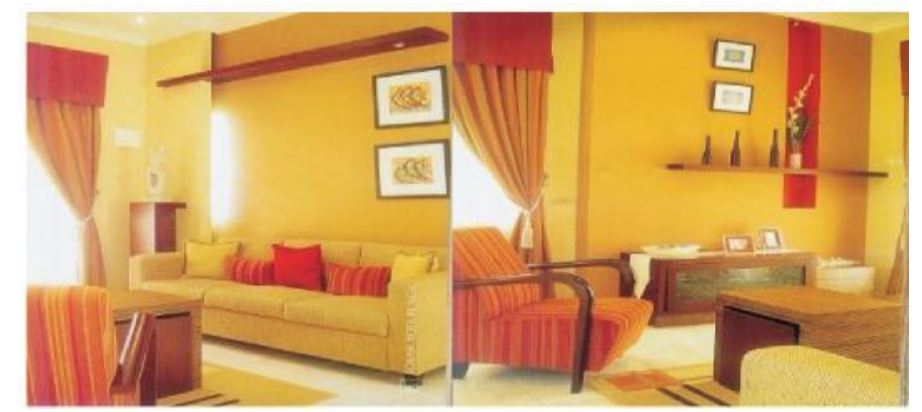

Gambar 2. Penggunaan warna natural dan warna-warna hangat untuk mencapai kesan hangat.

Suasana segar(fresh) dalam interior dapat diterapkan warna-warna yang segar dan berjiwa muda mengambil ispirasi dari alam seperti warna putih kebiruan (warna langit), hijau apel, kuning lemon, biru laut, dll (gambar .3). 


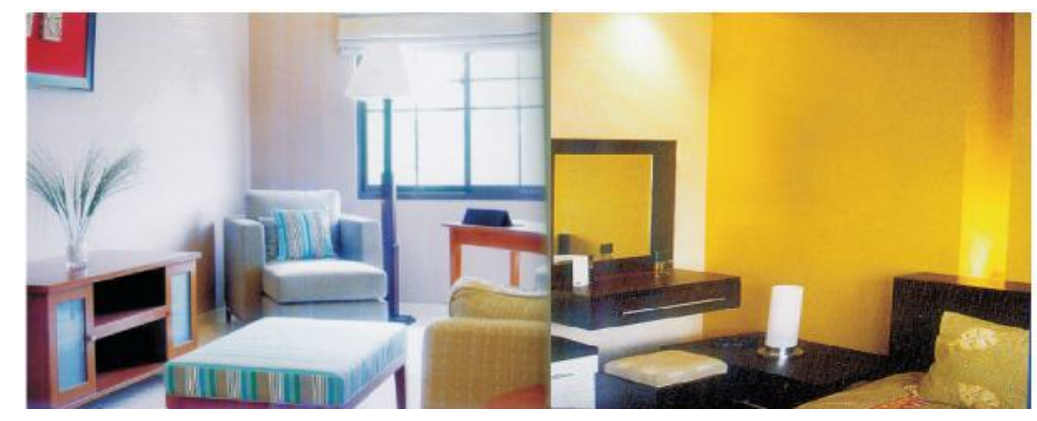

Gambar 3. Interior ruang baca dan ruang tidur yang menerapkan warna-warna segar untuk mencapai kesan segar (fresh).

\section{Aplikasi Warna pada Interior Rumah Sakit}

Rumah sakit merupakan lingkungan binaan yang harus dirancang sedemikian rupa sehingga dapat memberikan efek psikologi yang nyaman bagi proses penyembuhan pasien rawat inap. Untuk menciptakan ruang rawat inap yang dapat memberi kenyamanan bagi pasien, disamping sirkulasi udara yang harus baik, penerangan yang cukup, penyediaan jenis dan jumlah fasilitas yang disesuaikan dengan jenis aktivitas dan jumlah civitasnya, disamping itu tidak kalah penting penerapan warna yang tepat sehingga dapat mempengaruhi pisikologi pasien dalam proses penyembuhan.

Untuk mencapai efek psikologi yang nyaman bagi penyembuhan pasien terutama pasien rawat inap maka perlu adanya pengaplikasian warna yang tepat dalam perancangan desain interior kamar rawat inap. Langkah-langkah yang harus diketahui dalam pengaplikasian warna yang tepat untuk kamar rawat inap antara lain menciptakan kesan ruang dengan warna. Untuk itu kita perlu harus mengetahui besaran dari kamar rawat inap yang akan kita desain, yang menyangkut keluasan ruang, bentuk ruang, ketinggian plafond. Apabila ruang kamar rawat inap berukuran agak sempit maka untuk menciptakan kesan luas sebaiknya diterapkan warna-warna yang muda pada dinding, lantai dan plafon (gambar 4).

Sebaliknya dimensi ruang terlalu luas, maka untuk menciptakan kesan ruang lebih kecil gunakanlah warna-warna hangat pada dinding dan plafond (gambar 5). Apabila plafond pada ruang kamar rawat inap berdimensi agak sedikit rendah, maka untuk menciptakan kesan lebih tinggi dengan menerapkan warna yang lebih terang dari warna dinding dan lantai (gambar 6). Selanjutnya, untuk mengurangi dimensi plafond yang terlampau tinggi, sebaiknhya digunakan warna sedikit lebih gelap dari warna dinding (gambar 7).
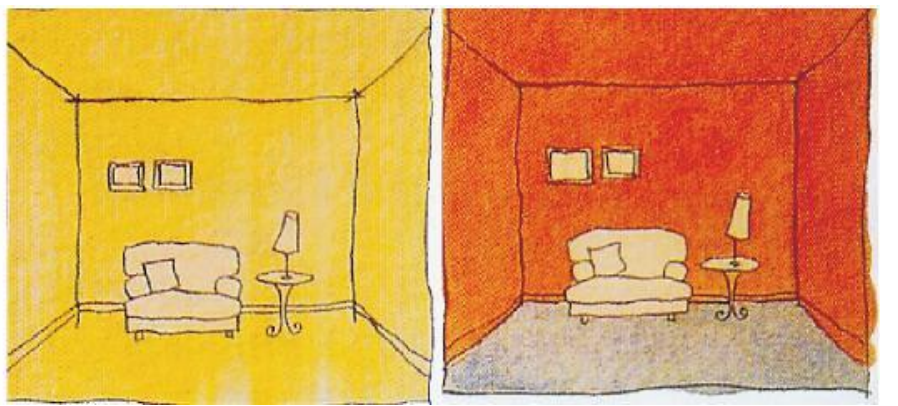

Gambar 4 dan 5: Penerapan warna untuk ruang sempit dan ruang yang terlalu luas.

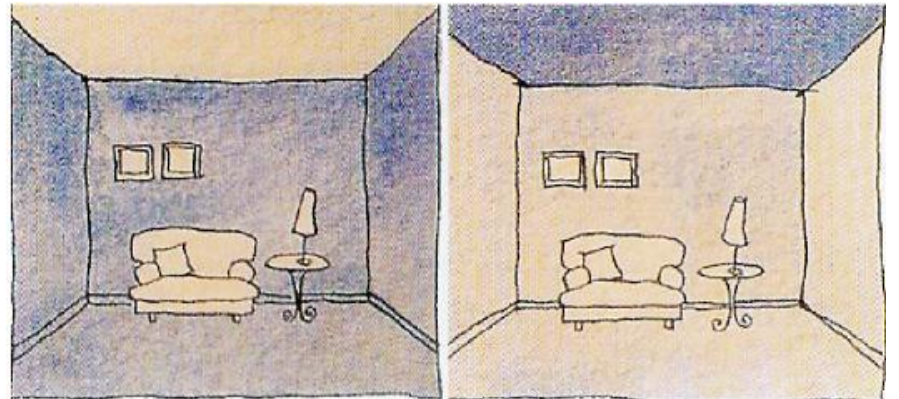

Gambar 6 dan7: Penerapan warna pada plafond rendah dan tinggi.

Pengaplikasikan warna pada keseluruhan desain interior kamar rawat inap disesuaikan dengan konsep yang diambil. Sedangkan konsep yang diambil disesuaikan dengan besaran ruang dan ketinggian plafond. Contoh apabila ruang kamar rawat inap tidak terlalu luas dengan ketinggian plafond yang tidak terlalu tinggi, kita bisa mengambil konsep tenang ( $\mathrm{calm}$ ) atau konsep segar. Dalam konsep tenang dapat diterapkan warna-warna lembut yang elegan (warna-warna pastel) seperi cream, biru muda, biru pucat, biru laut, unggu muda, hijau muda, hijau daun, hijau pupus, yang dipadukan dengan putih, tetapi tidak menutup kemungkinan menerapkan warna-warna hangat seperti merah, oranye pada bagian-bagian tertentu dengan skup kecil sebagai aksentuasi.Sedangkan konsep segar dapat diterapkan warna-warna muda yang mengambil inspirasi dari alam seperti warna oranye muda, putih (warna netral), hijau apel, hijau daun,hijau jeruk limau, kuning lemon, tetapi juga tetaptidak menutup kemungkinan untuk menerapkan warna hangat sebagai aksentuasi. Apabila kamar rawat inap memiliki besaran ruangan yang cukup luas dan dimensi plafond cukup tinggi maka dapat mengambil konsep hangat, dalam konsep ini dapat diterapkan warna-warna warna merah darah, merah marun dan oranye tua sebagai aksentuasi, oranye yang 
mengarah kecoklat, kuning muda, coklat tua sampai coklat muda, emas metalik, terakota, tetapi tidak tertutup juga untuk di padukan dengan warna-warna yang tergolong warna putih, warna-warnalembut dan alami. Biasanya ruang rawat inap yang memiliki besaran ruang cukup luas termasuk dalam room vip.

\section{SIMPULAN}

Penerapa warna yang tepat pada interior kamar rawat inap sebaiknya diperhatikan untuk membantu proses penyembuhan pasien karena penerapan warna yang tepat dapat member efek psikologi (kenyamanan) pada pasien sehingga dapat membantu mereduksi faktor strees.

Pengaplikasikan warna pada keseluruhan desain interior kamar rawat inap disesuaikan dengan konsep yang diambil. Sedangkan konsep yang diambil disesuaikan dengan besaran ruang. Apabila ruang kamar rawat inap tidak terlalu luas dan ketingian plafon rendah kita bias mengambil konsep tenang (calm) atau konsep segar (fresh). Dalam konsep tenang (calm) dapat diterapkan warna-warna lembut yang elegan (warna-warna pastel) seperi cream, biru muda, biru pucat, biru laut, unggu muda, hijau muda, hijau daun, hijau pupus, yang dipadukan dengan putih. Sedangkan konsep segar dapat diterapkan warna-warna muda yang mengambil inspirasi dari alam seperti warna oranye muda, putih (warna netral), hijau apel, hijau daun, hijau jeruk limau, kuning lemon. Dari kedua konsep tersebut tidak menutup kemungkinan untuk menerapkan warna hangat sebagai aksentuasi untuk menambah kesan ruang lebih hidup. Apabila kamar rawat inap memiliki besaran ruangan yang cukup luas dan memiliki ketinggian plafon cukup tinggi, maka dapat mengambil konsep hangat (warm), dalam konsep ini dapat diterapkan warna-warna warna merah darah, merah marun dan oranye tua sebagai aksentuasi, oranye yang mengarah ke coklat, kuning muda, coklat tua sampai coklat muda, emas metalik, terakota, tetapi tidak tertutup juga untuk di padukan dengan warna putih, warna-warnalembut dan warna-warna alami.

\section{DAFTAR PUSTAKA}

Altaman, Irwin.1987. Handbook of Environmental Psychologi (VolumeI). Canada: John Wiley \& Sons, Inc.

Gon H, Harry M, Budiarsa A, Pawang R. 2008. Kombinasi Warna (Serial Rumah). PT Prima Infosarana Media.

Kalpan, Robert M, Sallis Jr, James M. and Patteron, Thomas L. 1993. Health and Human Behavior. New York: Mc. Graw Hill Inc.

Manuabe A. 1997. Total Approach is a Must to Attain Sustainable Improvement of Working Conditions and Environment in Small Scale and Cottage Industry. International Coference on Occupations Health ang Safety in Small Scale Industry (ICOHIS), Kartika Plaza Kuta Bali.
Pile John F. 1995. Color in Interior Design. New York: Mc Graw-Hill

Sarwono, Sarlito W. 1995.Psikologi Lingkungan. Jakarta

Skinner Valerieann J. 2001. Cashing in on the"Simple Magic" of Colour. Publisher: Inner Light Creations.

Utomo, Eddy W. 1999. Karekteristik dan Fenomena Desain Interior Rumah Sakit Moderen. Makalah Seminar. 